\title{
A two-variable approach used to distinguish between aphids (Hemiptera: Aphididae) that were reared on different varieties of cotton
}

\author{
Yong-Sheng ZHANG ${ }^{1,2, *}$, FAng OUYANG ${ }^{1, *}$, Zhe-Ming YUAN ${ }^{2}, \mathrm{JING}_{\mathrm{CAO}} \mathrm{CA}^{1,2}$ and Feng GE Ge* $^{1, * *}$ \\ ${ }^{1}$ State Key Laboratory of Integrated Management of Pest and Rodents, Institute of Zoology, Chinese Academy of Sciences, Beijing, \\ China; e-mails: gef@ioz.ac.cn; yshzhang@yeah.net; ouyangf@ioz.ac.cn; 327240364@qq.com; 448631789@qq.com \\ ${ }^{2}$ College of Plant Protection, Hunan Agricultural University, Changsha, China
}

Key words. Hemiptera, Aphididae, Aphis gossypii, $\delta^{13} \mathrm{C}, \delta^{15} \mathrm{~N}$, dietary origins, cotton varieties

\begin{abstract}
Identifying the plants aphids have fed on can increase our understanding of their roles in food webs, and help in improving management and implementation control strategies in agricultural systems. Field sampling and laboratory experiments were carried out to determine the stable isotope ratios of carbon $\left(\delta^{13} \mathrm{C}\right)$ and nitrogen $\left(\delta^{15} \mathrm{~N}\right)$ in three different varieties of cotton and the aphids $($ Aphis gossypii) that fed on these varieties. The results were used to test the hypothesis that stable isotope signatures of aphids that have fed on different varieties of cotton differ. Two-dimensional plots of stable isotope signatures for aphids and the cotton varieties they fed on displayed a non-overlapping pattern, indicating that stable isotope signatures of the three cotton varieties and the aphids that fed on them differed. The results indicate that stable isotope analysis can potentially be used to identify aphids that have fed on different varieties of cotton. When the stable isotope signatures of diets clearly differ then it is highly likely the consumers will be distinguishable.
\end{abstract}

\section{INTRODUCTION}

Aphids are significant pests of agricultural crops worldwide and have a great economic effect mainly because of their rapid reproductive capacity and ability to manipulate host plant physiology (Powell et al., 2006; Goggin, 2007; Kuhlmann et al., 2013). Aphids are also widely used as model organisms in studies on population dynamics, speciation and biological diversity (Powell et al., 2006). Cotton, Gossypium spp., is a primary crop in Northern China, where this $\mathrm{C}_{3}$ plant is sown in summer and harvested in autumn. The cotton aphid, Aphis gossypii Glover, is an important pest of cotton (Wu \& Guo, 2005).

Methods for quantifying what an animal has fed on and the movement of pests aid our understanding of their roles in food webs and also help improve management and control strategies in agricultural landscapes. Many methods are used to determine what insects have fed on and track their movements within crop and/or non-crop habitats. These methods include antigen-antibody reactions (Dempster, 1960), gut content analyses (Isely \& Alexander, 1949; Marples, 1966), biological pigments (Putman, 1965), radioisotopes (Marples, 1966), direct observations of feeding insects (Petelle et al., 1979), and intrinsic markers such as fatty acid profiles (Smith et al., 1996; Guest et al., 2010), molecular DNA analyses and stable isotope analyses (Hobson, 1999). Stable isotopes are non-radioactive, persistent, intrinsically available labels that can indicate the long-term feeding behaviour of animals, features that facilitate their use in food web and diet studies (Peterson \& Fry, 1987; Schmidt et al., 1999; Hood-Nowotny \& Knols, 2007).
Stable isotope analysis of natural variations in animal tissue is a valuable tool for determining the source of the food of insects (Ostrom et al., 1997; Prasifka et al., 2004). There are many reports that stable isotopes can be used to distinguish between insects that have fed on either $\mathrm{C}_{3}$ or $\mathrm{C}_{4}$-plants (Schallhart et al., 2009; Ouyang et al., 2012, 2014). Our previous research found that the $\delta^{13} \mathrm{C}$ values of adult beetles of Propylea japonica that are first fed a $\mathrm{C}_{3}$ based diet (cotton aphids) and then $\mathrm{a}_{4}$-based diet (maize aphids) reflect the isotope ratio of the latter diet for one week. In addition, approximately $80-100 \%$ of the diet of $P$. japonica adults in maize originated from a $\mathrm{C}_{3}$-based sources in June, July and August, and approximately 80\% of the diet of those in an agricultural landscape composed of cotton and maize originated from $\mathrm{C}_{4}$-based sources in September (Ouyang et al., 2012).

However, few studies have shown that insects reared on different varieties of the same plant can be differentiated using isotope signatures analysis. We hypothesized that the stable isotope signatures of aphids that fed on different varieties of cotton differ. To test this hypothesis, field sampling and laboratory experiments were carried out. Our goals were: (1) To determine the $\delta^{13} \mathrm{C}, \delta^{15} \mathrm{~N}$ and nitrogen percentage $(\mathrm{N} \%)$ of three varieties of cotton and aphids that fed on them; (2) To identify the cotton variety using $\delta^{13} \mathrm{C}$ and $\delta^{15} \mathrm{~N}$ or $\delta^{13} \mathrm{C}$ and $\mathrm{N} \%$ values; (3) To identify the diet of aphids using $\delta^{13} \mathrm{C}$ and $\delta^{15} \mathrm{~N}$ or $\delta^{13} \mathrm{C}$ and $\mathrm{N} \%$ values; (4) To determine how closely stable isotope signatures of aphids that fed on various varieties of cottons reflect the host cotton signatures (assuming the signatures differ).

\footnotetext{
* These two authors contributed equally to this work.

** Corresponding author.
} 


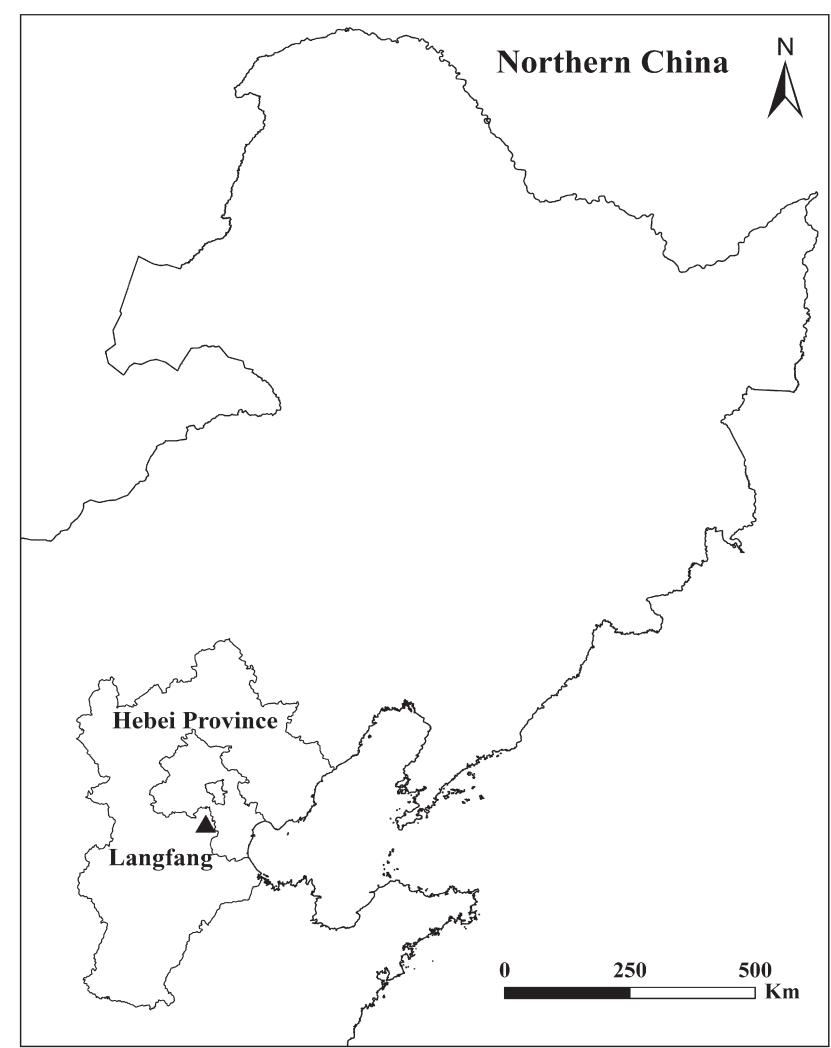

Fig. 1. Map showing the location of the study site in Hebei Province, China.

\section{MATERIAL AND METHODS}

\section{Field sampling and collecting}

Cotton and aphid samples were collected at the Langfang Experiment Station $\left(39.53^{\circ} \mathrm{N}, 116.70^{\circ} \mathrm{E}\right)$ in Hebei Province (Fig. 1), China, to establish the carbon and nitrogen stable isotope ratios of three different varieties of cotton (variety 1: Han-4849, 2: Simian-3 and 3: 93-56) and aphids reared on each of those varieties in the field. Samples of plant material were cut from the upper leaves of cotton, taking care to avoid the main leaf veins. Aphids were collected in groups of 50 or more by disturbing their colonies and collecting fallen or walking aphids using fine forceps.

\section{Sample preparation}

Aphids (Aphis gossypii) were separated from plant material using a scalpel into $\sim 20$ groups and samples of approximately 50 individuals were taken from each group. All of the aphid samples were dried for $72 \mathrm{~h}$ at $65^{\circ} \mathrm{C}$ before being weighed to an accuracy of $\pm 1 \mu \mathrm{g}$ and packaged in tin capsules. The capsules was labelled and stored.

All cotton leaf samples were frozen in a freezer and washed twice in reverse-osmosis filtered water. Accurate isotope analy- sis of large samples usually requires homogenization by grinding into a fine powder that is subsampled (Prasifka et al., 2004). Cotton samples were large enough to require homogenization. After drying for $72 \mathrm{~h}$ at $65^{\circ} \mathrm{C}$, leaf tissue was pulverized to a powder before enclosing a subsample $(2-3 \mathrm{mg})$ in a capsule.

\section{$\mathrm{C}$ and $\mathrm{N}$ stable isotope analyses}

Carbon or nitrogen stable isotope ratios $\left({ }^{13} \mathrm{C}:{ }^{12} \mathrm{C}\right.$ or $\left.{ }^{15} \mathrm{~N}:{ }^{14} \mathrm{~N}\right)$ are expressed as $\delta^{13} \mathrm{C}$ or $\delta^{15} \mathrm{~N}$, respectively, in a parts per thousand (\%) difference relative to a reference material (Hobson, 1999). These ratios are widely used in biological and ecological studies of arthropods (Gannes et al., 1997, 1998; Kelly, 2000; Dawson et al., 2002; Lepoint et al., 2004; Hood-Nowotny \& Knols, 2007).

For each sample of aphids and cotton plant material, data were collected for three variables: $\delta^{13} \mathrm{C}, \delta^{15} \mathrm{~N}$ and $\mathrm{N} \%$, which were measured at the Chinese Academy of Forestry's Stable Isotope Laboratory using a combustion-gas chromatography-mass spectrometry process. Stable isotope measurements were obtained using an elemental analyzer (Flash EA1112 HT) and a modified Finnigan MAT Delta V advantage isotope ratio mass spectrometer (Thermo Fisher, Waltham, MA, USA). Data were normalized using internationally accepted isotope standards (Pee Dee Belemnite for carbon, atmospheric $\mathrm{N}_{2}$ for nitrogen) in parts per thousand (\%) and the following equation:

$\delta X=\left[\left(R_{\text {sample }} / R_{\text {standard }}\right)-1\right] \times 1000$

where $X$ is ${ }^{13} \mathrm{C}$ or ${ }^{15} \mathrm{~N}$ and the $R_{\text {sample }}$ and $R_{\text {standard }}$ are the ratios of ${ }^{13} \mathrm{C} /{ }^{12} \mathrm{C}$ or ${ }^{15} \mathrm{~N} /{ }^{14} \mathrm{~N}$ for an individual sample and the analytical standard.

\section{Statistical analysis}

All statistical analyses were done using SPSS software (SPSS.17, 2008). C stable isotope $\left(\delta^{13} \mathrm{C}\right)$ was not correlated with $\mathrm{N}$ stable isotope $\left(\delta^{15} \mathrm{~N}\right)(r=0.344, P=0.149, N=19)$. Significance differences in individual factors were assessed using oneway analysis of variance (ANOVA). ANOVA followed by a LSD post hoc test was used to assess differences in $\delta^{13} \mathrm{C}, \delta^{15} \mathrm{~N}$ and $\mathrm{N} \%$ between trophic levels in a food chain (e.g., cotton variety 1 and the aphids that fed on it), among cotton varieties and among aphids.

\section{RESULTS}

\section{Carbon stable isotope ratios and their differences among food chains}

The $\delta^{13} \mathrm{C}$ values of three cotton varieties and aphids that fed on them are in Table 1. Analysis of the $\delta^{13} \mathrm{C}$ values revealed no significant differences in food chain 2 (cotton variety 2 and its aphids) or food chain 3 (cotton variety 3 and its aphids) (Fig. 2A, Table 2). Although the $\delta^{13} \mathrm{C}$ values of aphids that fed on cotton variety 1 were significantly lower than those of cotton variety 1 (Fig. 2A, Table 2), the mean differences, or isotopic shifts, between trophic levels in food chain 1 (cotton variety 1 and its aphids) were no more

TABLE 1. Means $\left( \pm\right.$ SE) of the $\delta^{15} \mathrm{~N}, \delta^{13} \mathrm{C}$ and $\mathrm{N} \%$ values recorded for three varieties of cotton and the aphids that were reared on them.

\begin{tabular}{lccc}
\hline Organisms & $\delta^{13} \mathrm{C}(\%)$ & $\delta^{15} \mathrm{~N}(\%)$ & $\mathrm{N}(\%)$ \\
\hline Cotton variety 1 & $-24.84 \pm 0.31$ & $-0.47 \pm 0.35$ & $3.15 \pm 0.16$ \\
Cotton variety 2 & $-26.39 \pm 0.11$ & $-0.74 \pm 0.44$ & $4.16 \pm 0.17$ \\
Cotton variety 3 & $-25.77 \pm 0.14$ & $-1.98 \pm 0.30$ & $4.69 \pm 0.23$ \\
Aphid reared on cotton variety 1 & $-26.12 \pm 0.11$ & $0.07 \pm 0.52$ & $5.27 \pm 0.33$ \\
Aphid reared on cotton variety 2 & $-26.58 \pm 0.05$ & $-2.02 \pm 0.02$ & $6.27 \pm 0.24$ \\
Aphid reared on cotton variety 3 & $-26.29 \pm 0.08$ & $-2.57 \pm 0.38$ & $6.67 \pm 0.11$ \\
\hline
\end{tabular}



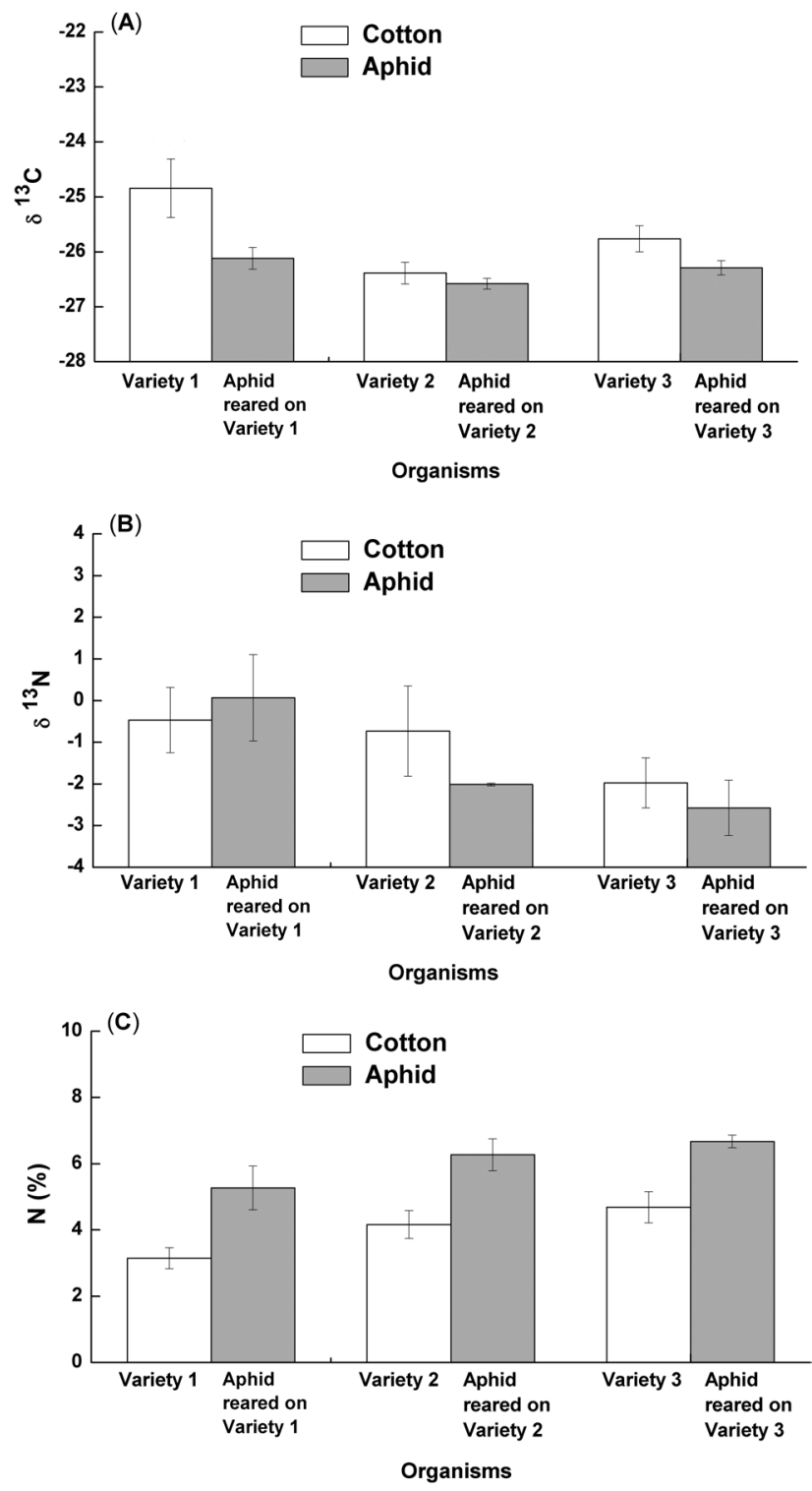

Fig. 2. Stable isotope ratios $\left(\delta^{13} \mathrm{C}, \delta^{15} \mathrm{~N}\right.$ and $\left.\mathrm{N} \%\right)$ recorded for the cotton plants and aphids in each of the three cotton-aphid food chains. Error bars represent \pm SD.

than $1.3 \%$ (isotopic shifts of $\delta^{13} \mathrm{C}$ from cotton variety 1 to its aphids).

There were significant differences in the $\delta^{13} \mathrm{C}$ values of the different varieties of cotton (Fig. 2A, Table 2). The $\delta^{13} \mathrm{C}$ values of cotton variety 1 were significantly higher than those of cotton variety 2 (LSD post hoc test, $p<0.0048$ ) and cotton variety 3 (LSD post hoc test, $p<0.0408$ ) (Fig.
TABle 3. $P$-values of LSD post hoc test of the $\delta^{13} \mathrm{C}, \delta^{15} \mathrm{~N}$ and $\mathrm{N} \%$ values recorded for the three varieties of cotton. ${ }^{*} P<0.05$, $* * P<0.01, * * * P<0.001$.

\begin{tabular}{cccccccc}
\hline \multirow{2}{*}{$\begin{array}{c}\text { Cotton } \\
\text { variety }\end{array}$} & \multicolumn{3}{c}{ Cotton variety 1} & & \multicolumn{3}{c}{ Cotton variety 2} \\
\cline { 2 - 4 } \cline { 6 - 8 } & $\delta^{13} \mathrm{C}$ & $\delta^{15} \mathrm{~N}$ & $\mathrm{~N} \%$ & & $\delta^{13} \mathrm{C}$ & $\delta^{15} \mathrm{~N}$ & $\mathrm{~N} \%$ \\
\hline 2 & $0.0048^{* *}$ & 0.6610 & $0.0058^{* *}$ & & & & \\
3 & $0.0408^{*}$ & $0.0409^{*}$ & $0.0006^{* * *}$ & 0.1306 & 0.0738 & 0.1056 \\
\hline
\end{tabular}

2A, Table 3). Significant differences were also recorded for the $\delta^{13} \mathrm{C}$ values of the aphids that fed on the three varieties (Fig. 2A, Table 2). The $\delta^{13} \mathrm{C}$ values of aphids that fed on cotton variety 1 were significantly higher than those that fed on cotton variety 2 (LSD post hoc test, $p<0.0103$, Fig. 2A, Table 4).

\section{Nitrogen stable isotope ratios and their differences among food chains}

The $\delta^{15} \mathrm{~N}$ values of the three varieties of cotton and the aphids that fed on them are in Table 1. Analysis of $\delta^{15} \mathrm{~N}$ values revealed no significant differences in either food chain 1, 2, or 3 (Fig. 2B, Table 2). The $\delta^{15} \mathrm{~N}$ values of cotton variety 1 were significantly higher than those of cotton variety 3 (LSD post hoc test, $p<0.0409$ ) (Fig. 2B, Table $3)$. For the aphids, the $\delta^{15} \mathrm{~N}$ values of those that fed on cotton variety 1 were significantly higher than those that fed on variety 2 (LSD post hoc test, $p<0.0080$ ) and 3 (LSD post hoc test, $p<0.0034$ ) (Fig. 2B, Table 4).

\section{Nitrogen percentages and their differences among food chains}

The $\mathrm{N} \%$ values of the three varieties of cotton and the aphids that fed on them are in Table 1. Analysis of the N\% values revealed significant differences in food chains 1,2 and 3 (Fig. 2C, Table 2). Mean differences in N\% in food chain 1 were $2.13 \%$ (isotopic shifts from cotton variety 1 to its aphids), $2.11 \%$ in food chain 2 and $1.98 \%$ in food chain 3 .

There were significant differences in $\mathrm{N} \%$ among the varieties of cotton (Fig. $2 \mathrm{C}$, Table 2). The N\% values of variety 1 were significantly lower than those of varieties 2 (LSD post hoc test, $p<0.0058$ ) and 3 (LSD post hoc test, $p<0.0006$ ) (Fig. 2C, Table 3). Similarly, significant differences in $\mathrm{N} \%$ were also recorded for the aphids (Fig. 2C, Table 2), with the N\% values of those that fed on variety 1 significantly lower than those that fed on varieties 2 (LSD post hoc test, $p<0.0443$ ) and 3 (LSD post hoc test, $p<$ 0.0148) (Fig. 2C, Table 4).

TABLE 2. One-way ANOVA of the $\delta^{13} \mathrm{C}, \delta^{15} \mathrm{~N}$ and $\mathrm{N} \%$ values recorded for the three cotton aphid food chains. $* P<0.05$, ${ }^{*} * P<0.01$, $* * * P<0.001$.

\begin{tabular}{|c|c|c|c|c|c|c|c|c|c|}
\hline \multirow{2}{*}{ Subject } & \multicolumn{3}{|c|}{$\delta^{13} \mathrm{C}$} & \multicolumn{3}{|c|}{$\delta^{15} \mathrm{~N}$} & \multicolumn{3}{|c|}{$\mathrm{N} \%$} \\
\hline & $\mathrm{df}$ & $F$ & $P$ & df & $F$ & $P$ & df & $F$ & $P$ \\
\hline Food chain 1 & 1,4 & 10.0563 & $0.0338 *$ & 1,7 & 0.6028 & 0.4629 & 1,6 & 24.9852 & $0.0025 * *$ \\
\hline Food chain 2 & 1,5 & 2.0664 & 0.2101 & 1,8 & 4.5039 & 0.0666 & 1,8 & 42.6508 & $0.0002 * * *$ \\
\hline Food chain 3 & 1,4 & 7.5607 & 0.0514 & 1,5 & 1.1177 & 0.3388 & 1,5 & 34.5788 & $0.0020 * *$ \\
\hline Cotton & 2,6 & 9.5722 & $0.0136^{*}$ & 2,12 & 2.9271 & 0.0922 & 2,11 & 11.6314 & $0.0019 * *$ \\
\hline Aphids & 2,7 & 6.3407 & $0.0268 *$ & 2,8 & 10.1073 & $0.0065 * *$ & 2,8 & 5.3628 & $0.0333 *$ \\
\hline
\end{tabular}



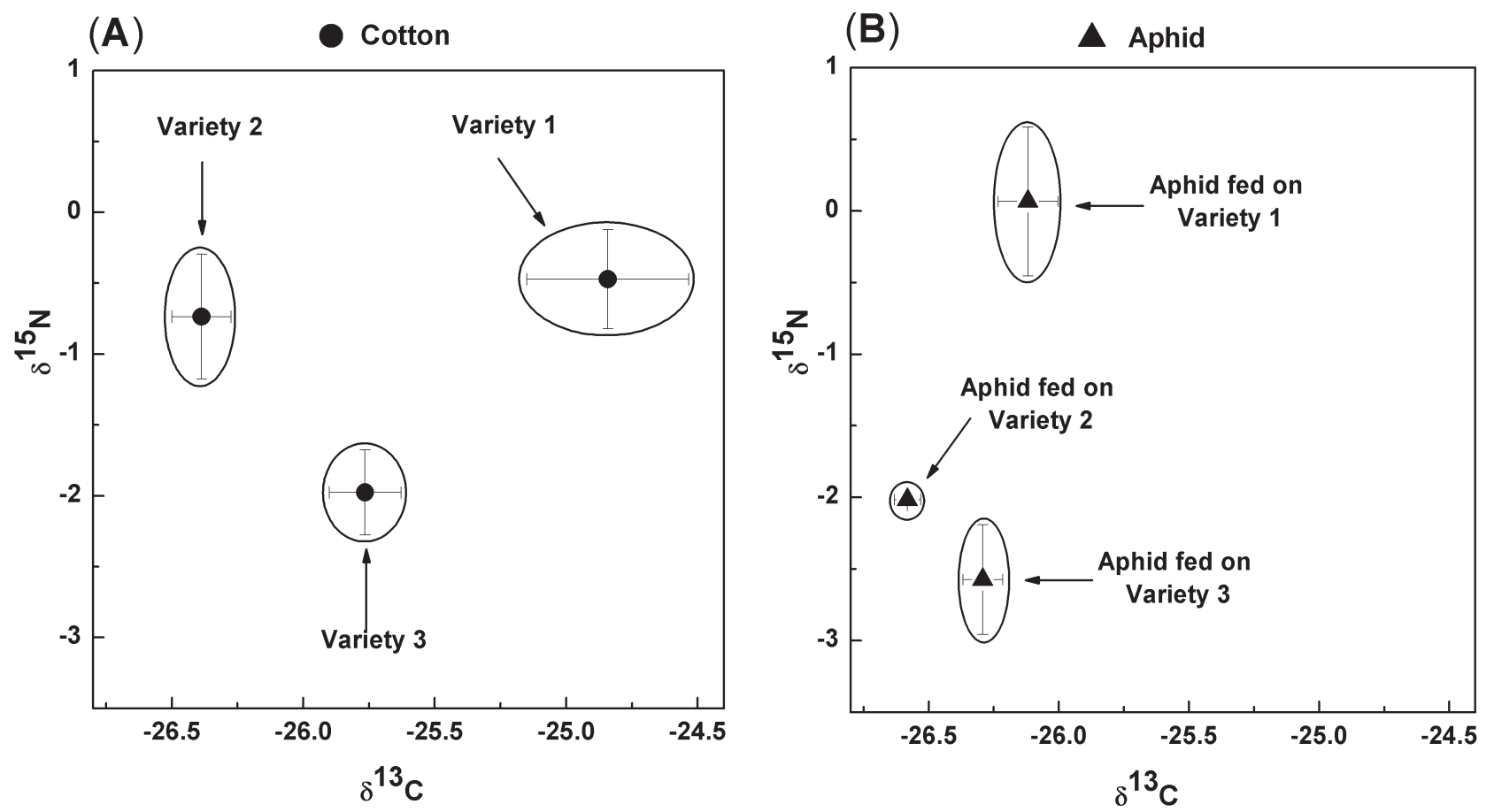

(C)

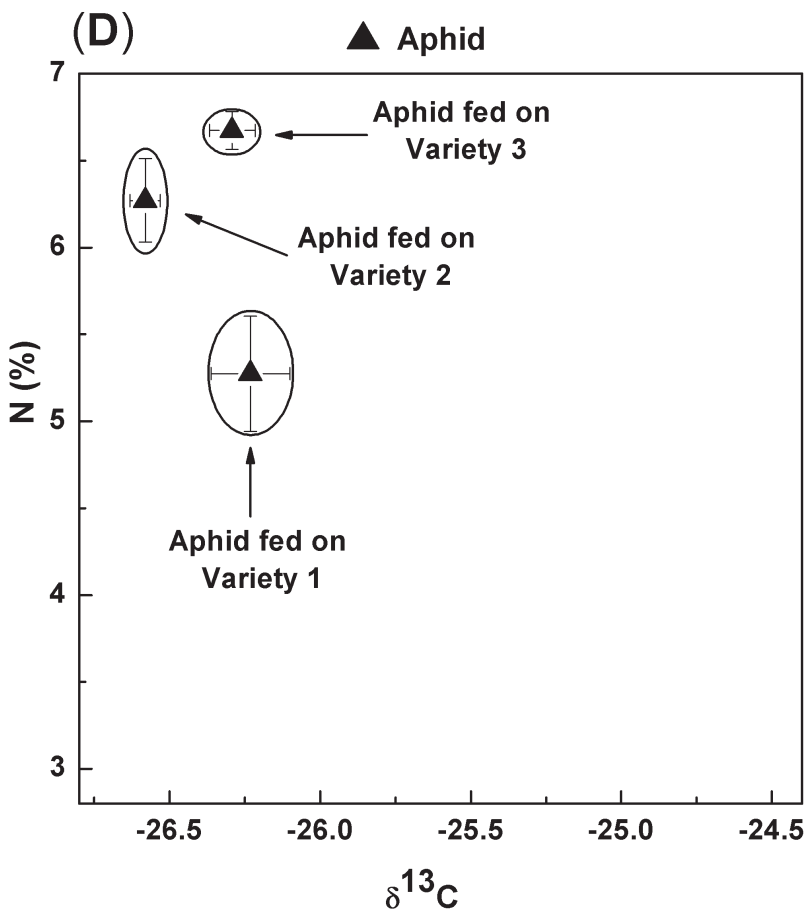

Fig. 3. Two-dimensional analysis of $\mathrm{C}$ and $\mathrm{N}$ stable isotope ratios recorded for the three varieties of cotton and the aphids that were reared on them. Error bars represent \pm SE. (A) $\delta^{13} \mathrm{C}$ vs. $\delta^{15} \mathrm{~N}$ for cotton. (B) $\delta^{13} \mathrm{C}$ vs. $\delta^{15} \mathrm{~N}$ for aphids. (C) $\delta^{13} \mathrm{C}$ vs. N\% for cotton. (D) $\delta^{13} \mathrm{C}$ vs. N\% for aphids.

Two-dimensional analysis of carbon and nitrogen stable isotope ratios of three varieties of cotton and the aphids that fed on them

The non-overlapping pattern in the two-dimensional plots of the stable isotope signatures of aphids and the varieties of cotton they fed on (Fig. 3) indicates that a combination of only two variables is sufficient for distinguishing between the different varieties of cotton and the aphids that fed on them. It was possible to identify the three varieties of cotton (Fig. 3A) and the aphids that fed on them (Fig. 3B) (Table 1) by combining the values of $\delta^{13} \mathrm{C}$ and $\delta^{15} \mathrm{~N}$ in two-dimensional analyses. In addition, two-variable analyses using $\delta^{13} \mathrm{C}$ and $\mathrm{N} \%$ values also identified the three varieties of cotton (Fig. 3C) and the aphids that fed on them (Fig. 3D) (Table 1).

\section{DISCUSSION}

Changes in isotopic signatures of the consumed and the consumer occur during food assimilation and excretion. 
TABLE 4. $P$-values of LSD post hoc test of the $\delta^{13} \mathrm{C}, \delta^{15} \mathrm{~N}$ and $\mathrm{N} \%$ values recorded for the aphids that were reared on the three varieties of cotton. $* P<0.05, * * P<0.01, * * * P<0.001$.

\begin{tabular}{|c|c|c|c|c|c|c|}
\hline & \multicolumn{3}{|c|}{ Aphid reared on cotton variety 1} & \multicolumn{3}{|c|}{ Aphid reared on cotton variety 2} \\
\hline & $\delta^{13} \mathrm{C}$ & $\delta^{15} \mathrm{~N}$ & $\mathrm{~N} \%$ & $\delta^{13} \mathrm{C}$ & $\delta^{15} \mathrm{~N}$ & $\mathrm{~N} \%$ \\
\hline Aphid reared on cotton variety 2 & $0.0103 *$ & $0.0080 * *$ & $0.0443 *$ & & & \\
\hline Aphid reared on cotton variety 3 & 0.2613 & $0.0034 * *$ & $0.0148 *$ & 0.0662 & 0.4088 & 0.4010 \\
\hline
\end{tabular}

The variability in the degree of the isotopic shift in $\delta^{13} \mathrm{C}$ between trophic levels ranges from -2.7 to $+3.3 \%$ (Sagers $\&$ Goggin, 2007). Here, isotopic shifts in $\Delta \delta^{13} \mathrm{C}$ values were in this range with a mean difference in $\Delta \delta^{13} \mathrm{C}$ between cotton variety 1 and the aphids that fed on it of $1.28 \%$, variety 2 and the aphids that fed on it of $0.19 \%$ and variety 3 and the aphids that fed on it of $0.53 \%$. The $\delta^{13} \mathrm{C}$ values of cotton aphids were higher than the corresponding values for the varieties of cotton they fed on in all three food chains. Isotopic analysis of organisms in a food web can provide information about trophic relationships and be used to identify what a particular organism has eaten (Hood-Nowotny \& Knols, 2007). The $\delta^{13} \mathrm{C}$ values of animals in most cases are similar to that of their diets (Deniro \& Epstein, 1978). The $\delta^{13} \mathrm{C}$ values can be used to differentiate aphids that fed on variety 1 from those that fed on variety 2 , probably because the $\delta^{13} \mathrm{C}$ values of variety 1 were distinctly higher than those of variety 2 .

The variability in the degree of the shift in the $\delta^{15} \mathrm{~N}$ values between trophic levels ranges from -2.1 to $+5.4 \%$ o (Sagers \& Goggin, 2007). The isotopic shifts in $\Delta \delta^{15} \mathrm{~N}$ values between trophic levels recorded in this study were in this range, with the mean differences for $\Delta \delta^{15} \mathrm{~N}$ between variety 1 and the aphids that fed on it of $-0.54 \%, 1.28 \%$ for food chain 2 and $0.60 \%$ for food chain 3 . As insects that feed on plant sap, aphids are frequently reported to show no enrichment or even depletion in ${ }^{15} \mathrm{~N}$ relative to that in their diet (Scrimgeour et al., 1995; McCutchan et al., 2003; Sagers \& Goggin, 2007; Schumacher \& Platner, 2009). Our results indicate that cotton aphids have a simi$\operatorname{lar} \delta^{15} \mathrm{~N}$ to that of their hosts, with the values for the aphids that fed on variety 2 and variety 3 not significantly different, but those fed on variety 1 richer in $\delta^{15} \mathrm{~N}$ than their diets. This study indicates that the $\delta^{15} \mathrm{~N}$ values can be used to differentiate between aphids that fed on variety 1 and those that fed on variety 3 , because the $\delta^{15} \mathrm{~N}$ values of the former were distinctly higher and similar to the $\mathrm{N} \%$ values.

Ideally, the stable isotope signature in aphids, as plant phloem feeders, should be analyzed relative to that of the phloem sap. This was not possible because of the technical difficulties of collecting sufficient quantities of phloem sap for stable isotope analysis. Results of previous aphid/ host studies indicate that the isotope signature of plant leaf tissue does not differ significantly from that of phloem sap and is used as a reliable proxy for phloem sap when measuring stable isotope ratios (Yoneyama et al., 1997; Sagers \& Goggin, 2007; Wilson et al., 2011). But using this proxy indicates a greater isotopic shift between trophic levels than recorded in this study, which might also account for the $\mathrm{N} \%$ value of consumers being distinctly higher than that recorded for their diets.
Using two stable isotope ratios (e.g., $\delta^{13} \mathrm{C}$ and $\delta^{15} \mathrm{~N}$ ) in analyses rather than one can provide a clearer differentiation between diets (Hood-Nowotny \& Knols, 2007; Ouyang et al., 2014; Brewitt et al., 2015). Wild-caught Drosophila exhibit interspecific differences in isotope signatures reflecting the four groups of host plants they feed on (Markow et al., 2000). In this study, neither the $\delta^{13} \mathrm{C}$ or $\delta^{15} \mathrm{~N}$ values alone could differentiate the three varieties of cotton, but by using both these values it is possible, as they then segregate into a non-overlapping pattern of distinctive stable isotope signatures in plots of $\delta^{13} \mathrm{C}$ vs. $\delta^{15} \mathrm{~N}$ or plots of $\delta^{13} \mathrm{C}$ vs. N\%. The distinctive $\delta^{13} \mathrm{C}$ values of the different varieties of cotton were transferred to the aphids that fed on them with little further change; similarly, different $\delta^{15} \mathrm{~N}$ or $\mathrm{N} \%$ values of diets also are passed on to the consumers. Consequently, the larger the differences in the isotope signatures of the diets, the more easily their consumers can be identified using stable isotope analysis.

Our study indicates that stable isotope signatures can be used to identify three varieties of cotton and the aphids that fed on them by segregating these organisms into nonoverlapping groups in two-dimensional diagrams. When stable isotope signatures of the diets are clearly different, the consumers are more likely to be distinguishable. Stable isotope analysis can potentially identify which aphids feed on which variety of cotton. This study was not meant to be an exhaustive description of the relationships between different varieties of cotton and the aphids that feed on them based on stable isotope ratios; rather, we were interested in whether their stable isotope ratios were different enough to distinguish between the plants and the aphids that fed on them, which we have shown to be the case.

ACKNOWLEDGEMENTS. This project was supported by "National Basic Research Program of China" (973 Program) (No. 2013CB127604), National Nature Science Fund of China (No. 31300347).

\section{REFERENCES}

Brewitt K., Piñol J., Werner C., Beyschlag W., Espadaler X., Hidalgo N.P. \& Platner C. 2015: Evaluating the importance of trophobiosis in a mediterranean ant community: A stable isotope analysis. - Insect Soc. 62: 81-95.

Dawson T.E., Mambelli S., Plamboeck A.H., Templer P.H. \& Tu K.P. 2002: Stable isotopes in plant ecology. - Annu. Rev. Ecol. Syst. 33: 507-559.

DeMPSTER J.P. 1960: A quantitative study of the predators on the eggs and larvae of the broom beetle, Phytodecta olivacea Forster, using the precipitin test. — J. Anim. Ecol. 29: 149-167.

Deniro M.J. \& EPSTEIN S. 1978: Influence of diet on distribution of carbon isotopes in animals. - Geochim. Cosmochim. Acta 42: 495-506. 
Gannes L.Z., O’Brien D.M. \& del Rio C.M. 1997: Stable isotopes in animal ecology: Assumptions, caveats, and a call for more laboratory experiments. -Ecology 78: 1271-1276.

GanNes L.Z., DEL Rio C.M. \& Koch P. 1998: Natural abundance variations in stable isotopes and their potential uses in animal physiological ecology. - Comp. Biochem. Physiol. (A) 119: $725-737$.

GogGin F.L. 2007: Plant-aphid interactions: Molecular and ecological perspectives. - Curr. Opin. Plant Biol. 10: 399-408.

Guest M.A., Hirst A.J., Nichols P.D. \& Frusher S.D. 2010: Multi-scale spatial variation in stable isotope and fatty acid profiles amongst temperate reef species: Implications for design and interpretation of trophic studies. - Mar. Ecol. Prog. Ser. 410: $25-41$.

Hobson K.A. 1999: Tracing origins and migration of wildlife using stable isotopes: A review. - Oecologia 120: 314-326.

Hood-Nowotny R. \& Knols B.G.J. 2007: Stable isotope methods in biological and ecological studies of arthropods. - Entomol. Exp. Appl. 124: 3-16.

Isely F.B. \& AleXAnder G. 1949: Analysis of insect food habits by crop examination. - Science 109: 115-116.

KelLy J.F. 2000: Stable isotopes of carbon and nitrogen in the study of avian and mammalian trophic ecology. - Can. J. Zool. 78: 1-27.

Kuhlmann F., Opitz S.E., Inselsbacher E., Ganeteg U., Nasholm T. \& NinKOVIC V. 2013: Exploring the nitrogen ingestion of aphids - a new method using electrical penetration graph and ${ }^{15} \mathrm{~N}$ labelling. - PLOS ONE 8: e83085.

Lepoint G., Dauby P. \& Gobert S. 2004: Applications of $\mathrm{c}$ and $\mathrm{n}$ stable isotopes to ecological and environmental studies in seagrass ecosystems. - Mar. Pollut. Bull. 49: 887-891.

Markow T.A., Anwar S. \& Pfeiler E. 2000: Stable isotope ratios of carbon and nitrogen in natural populations of Drosophila species and their hosts. - Funct. Ecol. 14: 261-266.

Marples T.G. 1966: A radionuclide tracer study of arthropod food chains in a Spartina salt marsh ecosystem. - Ecology 47: $270-277$

McCutchan J.H., Lewis W.M., Kendall C. \& McGrath C.C. 2003: Variation in trophic shift for stable isotope ratios of carbon, nitrogen, and sulfur. - Oikos 102: 378-390.

Ostrom P.H., Colunga Garcia M. \& Gage S.H. 1997: Establishing pathways of energy flow for insect predators using stable isotope ratios: Field and laboratory evidence. - Oecologia 109: 108-113.

Ouyang F., Men X.Y., Yang B., Su J.W., Zhang Y.S., Zhao Z.H. \& GE F. 2012: Maize benefits the predatory beetle, Propylea japonica (Thunberg), to provide potential to enhance biological control for aphids in cotton. - Plos ONE 7: e44379.
Ouyang F., Yang B., CaO J., Feng Y. \& Ge F. 2014: Tracing prey origins, proportions and feeding periods for predatory beetles from agricultural systems using carbon and nitrogen stable isotope analyses. - Biol. Contr. 71: 23-29.

Petelle M., Haines B. \& Haines E. 1979: Insect food preferences analyzed using c-13-c-12 ratios. - Oecologia 38: 159-166.

Peterson B.J. \& Fry B. 1987: Stable isotopes in ecosystem studies. - Annu. Rev. Ecol. Syst. 18: 293-320.

Powell G., Tosh C.R. \& Hardie J. 2006: Host plant selection by aphids: Behavioral, evolutionary, and applied perspectives. Annu. Rev. Entomol. 51: 309-330.

PrasifKa J.R., Heinz K.M. \& Winemiller K.O. 2004: Crop colonisation, feeding, and reproduction by the predatory beetle, Hippodamia convergens, as indicated by stable carbon isotope analysis. - Ecol. Entomol. 29: 226-233.

PutMan W.L. 1965: Paper chromatography to detect predation on mites. - Can. Entomol. 97: 435-441.

SAgers C.L. \& GogGin F.L. 2007: Isotopic enrichment in a phloem-feeding insect: Influences of nutrient and water availability. -Oecologia 151: 464-472.

Schallhart N., Wallinger C., Juen A. \& Traugott M. 2009: Dispersal abilities of adult click beetles in arable land revealed by analysis of carbon stable isotopes. - Agr. Forest Entomol. 11: 333-339.

Schmidt O., Scrimgeour C.M. \& Curry J.P. 1999: Carbon and nitrogen stable isotope ratios in body tissue and mucus of feeding and fasting earthworms (Lumbricus festivus). _ Oecologia 118: 9-15.

Schumacher E. \& Platner C. 2009: Nutrient dynamics in a tritrophic system of ants, aphids and beans. - J. Appl. Entomol. 133: 33-46.

Scrimgeour C.M., Gordon S.C., Handley L.L. \& Woodford J.A.T. 1995: Trophic levels and anomalous $\delta^{15} \mathrm{~N}$ of insects on raspberry (Rubus idaeus L). - Isot. Environ. Health Stud. 31: $107-115$.

Smith R.J., Hobson K.A., Koopman H.N. \& Lavigne D.M. 1996: Distinguishing between populations of fresh- and salt-water harbour seals (Phoca vitulina) using stable-isotope ratios and fatty acid profiles. - Can. J. Fish. Aquat. Sci. 53: 272-279.

Wilson A.C., da SL Sternberg L. \& Hurley K.B. 2011: Aphids alter host-plant nitrogen isotope fractionation. - PNAS 108: 10220-10224

Wu K.M. \& Guo Y.Y. 2005: The evolution of cotton pest management practices in china. - Annu. Rev. Entomol. 50: 31-52.

Yoneyama T., Handley L., Scrimgeour C., Fisher D. \& Raven J. 1997: Variations of the natural abundances of nitrogen and carbon isotopes in Triticum aestivum, with special reference to phloem and xylem exudates. - New Phytol. 137: 205-213.

Received August 4, 2014; revised and accepted March 9, 2015 Prepublished online May 15, 2015 